Proceedings

\title{
Carbon Dioxide Emissions from a Ground Heat Pump for a Detached House ${ }^{+}$
}

\author{
Sara Sewastianik ${ }^{1}$ and Andrzej Gajewski ${ }^{2, *}$ \\ 1 Students' Scientific Society “Heat Engineer”, Bialystok University of Technology, Wiejska Street 45 A, 15- \\ 351 Białystok, Poland; sa.sewastianik@vp.pl \\ 2 Department of HVAC Engineering, Faculty of Civil Engineering and Environmental Engineering, \\ Bialystok University of Technology, Wiejska Street 45 A, 15-351 Białystok, Poland \\ * Correspondence: a.gajewski@pb.edu.pl; Tel.: +48-797-995-923 \\ † Presented at Innovations-Sustainability-Modernity-Openness Conference (ISMO'19), Bialystok, Poland, \\ 22-23 May 2019.
}

Published: 20 June 2019

\begin{abstract}
Inasmuch as the European Union promotes only energetically viable heat pumps in a given location, the aim of the work is an assessment of whether a ground-to-water heat pump (ground source heat pump: GSHP) can be considered as an ecological heat generator in Polish climatic conditions and those of the energy market. Here, as an estimator, the net seasonal coefficient of performance (SCOPnet) was selected. Estimation was done using 10-year temperature measurements. It was found that in heating mode SCOPnet value equaled 4.83, satisfying European Commission guidelines. According to the guidelines, the minimal SCOP net value in Polish energy market conditions should exceed 3.5. $\mathrm{CO}_{2}$ emissions from the GSHP represented two-thirds of $\mathrm{CO}_{2}$ emissions of an air-to-water heat pump (air source heat pump: ASHP) in the same building. The ground heat pump thus meets the ecological heat generator conditions set by the European Commission.
\end{abstract}

Keywords: seasonal coefficient of performance; ground-to-water heat pump; GSHP; geothermal energy

\section{Introduction}

Increasing temperature, which has been observed for over a century, has led to international agreements such as the Kyoto Protocol and regulations such as European Union directives [1], where renewable energy sources (RES) are promoted. Heat pumps, which produce heat without the necessity for combustion of fossil fuels directly, represent an area of heat engineering. Generally, there are two low-temperature sources in the case of heat pumps: the Sun and the Earth's inner core. Air-to-water heat pumps fail EU requirements [1] in Polish energy market conditions [2,3], due to too-low temperature values during the heating season. Since the temperature below the shallow zone is stable and at a sufficiently high level [4], the Earth's inner core has higher energetic potential in a given location. Hence, the water-to-water heat pump satisfies EU requirements [5]. However, ground water basins are not ubiquitous. Thus, the purpose of the work is to assess whether ground-to-water heat pumps can be considered as ecological heat generators.

\section{The Computation Algorithm}

Only the heat pump, which produces significantly more heat than it uses with respect to primary energy to drive itself, is able to be promoted in European Economic Area states [1]. The best assessment factor seems to be $\mathrm{SCOP}$ net, which in the case of Polish market conditions should be higher 
than 3.5 (cf. Rubik [6]). Here, an estimation is made for a case study of a building in which the design heat load is $11 \mathrm{~kW}$, located in the fourth climate zone in Poland. It is based on temperature measurements carried out by the Institute of Meteorology and Water Management-National Research Institute (IMGW-PIB). The number of hours with each temperature value are counted in the 10 consecutive heating seasons. Then, the number of hours is converted to one Julian year $(365.25$ days) which is denoted as annus (abbr. "a"). The building is supplied with heat by the Vitocal 200-G, type 201.A13 heat pump manufactured by Viessmann (Allendorf, Germany) [7].

\subsection{Seasonal Coefficient of Performance Determination}

The calculations are performing using ground temperature determination, which is done using Baggs formula [7,8] after an adaptation to Polish climatic conditions made by Popiel et al. [9]:

$$
t(z, \tau)=\left(t_{a}+\Delta t_{m}\right)-1.07 k_{v} A_{s} \exp \left(-0.00031552 z a^{-0.5}\right) \cos \left[\frac{2 \pi}{365}\left(\tau-\tau_{o}-0.018335 z a^{-0.5}\right)\right] \quad\left[{ }^{\circ} \mathrm{C}\right]
$$

where $\Delta t_{m}$ is a difference between ground temperature below shallow zone and average annual air temperature, $k_{v}$ is vegetation coefficient, $A_{s}$ is the amplitude of annual air temperature, $a$ is the soil thermal diffusivity, $\tau_{\mathrm{o}}$ is the phase shift of the air temperature wave, and $t_{a}$ is average annual air temperature.

Ground temperature was determined after integral averaging of Equation (1). Then, SCOPnet was determined in all the values of the outside temperature at which the device operates. This depends on the change of the outside air temperature and temperature of the low temperature source. Then, the part load for heating at each bin temperature value is fixed using the standard 14825:2016-08 [10]:

$$
P_{h}\left(t_{j}\right)=\Phi_{i} \frac{\left(t_{i}-t_{j}\right)}{\left(t_{i}-t_{e}\right)}[k W]
$$

where $\Phi_{\mathrm{i}}$ is total design heat loss obtained using an algorithm from PN-EN 12831 [11], $t_{i}$ is the internal design temperature, assumed to be $20^{\circ} \mathrm{C}, t_{j}$ is the external air temperature, and $t_{e}$ is the external design temperature.

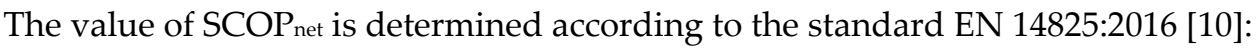

$$
\operatorname{SCOP}_{n e t}=\frac{\sum_{j=1}^{n} h_{j}\left[P_{h}\left(t_{j}\right)\right]}{\sum_{j=1}^{n} h_{j}\left[\frac{P_{h}\left(t_{j}\right)}{\operatorname{COP} P_{\text {bin }}\left(t_{j}\right)}\right]}[\mathrm{kW}]
$$

where $h_{j}$ is number of bin hours occurring at external temperature $t_{j}$ in the heating season, COPbin $\left(t_{j}\right)$ is the COP value of the unit at external temperature $t_{j}$ (coefficient of performance at part load), and $j$ is the number of a temperature value (the temperature values are sorted in ascending order).

\subsection{Carbon Dioxide Emission Ascertainment}

Carbon dioxide emissions are divided into direct and indirect emissions. The former originates from fuel combustion in a location when temperature is below a bivalent point, while the latter results from electricity generation for boiler system operation and heat production by heat pump at or above a bivalent point:

$$
E_{c O_{2}}=\sum_{j=0}^{m} h_{j}\left[\frac{\beta_{g a s} P_{h}\left(t_{j}\right)}{\eta_{b}}+\beta_{a g} W_{r u n j}\right]+\beta_{a g} \sum_{j=m+1}^{n} h_{j}\left[\frac{P_{h}\left(t_{j}\right)}{C O P_{b i n}\left(t_{j}\right)}\right]\left[\mathrm{kgCO}_{2} / a\right]
$$

where $\beta_{g a s}$ represents the carbon dioxide emissions from natural gas combustion, $W_{r u n}$ is the energy consumption for boiler system operation, $\beta_{a g}$ is the aggregate carbon dioxide generation factor which accounts for direct and indirect emissions amid electrical energy production and considers shares of all the fuels in the Polish energy market (cf. PGE Obrót S.A. [12]), and $m+1$ is the number of $t_{j}=-2.9$ 
${ }^{\circ} \mathrm{C}$, the bivalent temperature when the air-to-water heat pump (ASHP) starts [2]. In the case of the ground-to-water heat pump (GSHP), $m=0$, as the GSHP operates during the entire heating season and there is no bivalent heat generator; thus, the left summand in Equation (4) is equal to zero.

\section{Results}

COP bin values increase from 3.05 at $-29.8^{\circ} \mathrm{C}$ (i.e., the lowest measured temperature during the 10 -year period) to 5.57 at $12{ }^{\circ} \mathrm{C}$ when the heating system switches off. Here, $\mathrm{SCOP}_{\text {net }}=4.83$. COP bin values at each bin temperature value of the analyzed device and the averaged value of the SCOPnet coefficient are presented in Figure 1.

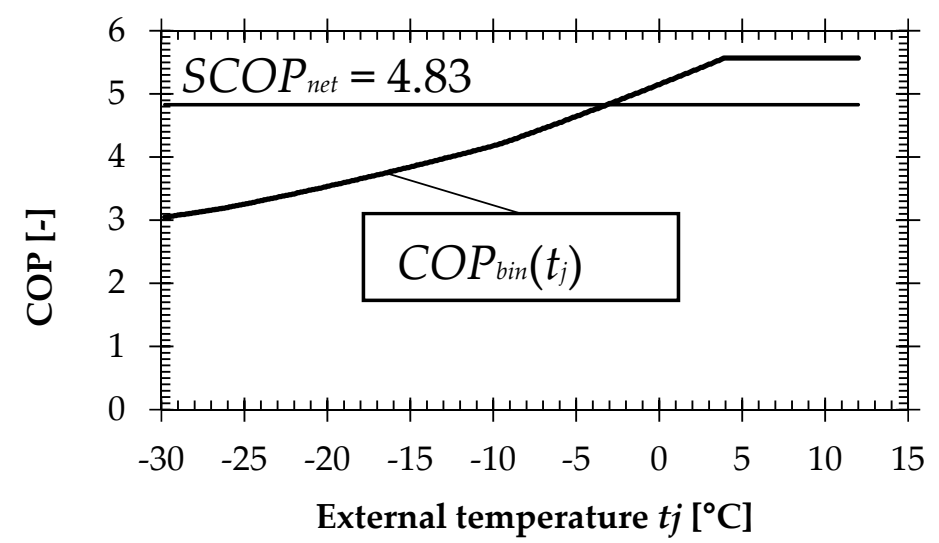

Figure 1. COP of GSHP in dependence on external temperature value, SCOPnet value obtained from Equation (3).

Carbon dioxide emissions are calculated for GSHP and ASHP, as investigated earlier [2]. ASHP $\left(\mathrm{SCOP}_{\text {net }}=2.55\right)$ had a condensed gas boiler as a bivalent heat generator [2]. Obtained emissions are plotted in Figure 2.

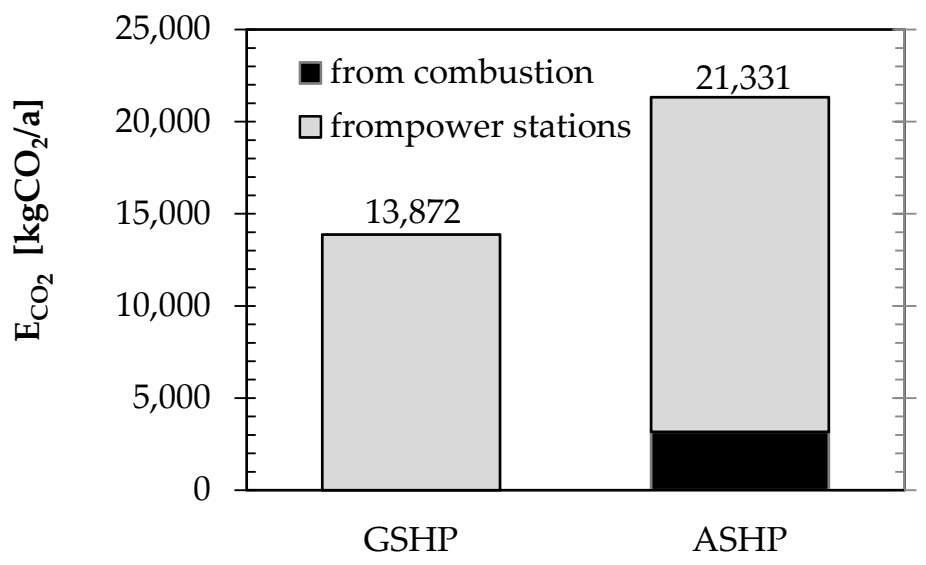

Figure 2. Carbon dioxide emissions form the two considered heat generators.

\section{Discussion}

The determined SCOP net value satisfies the guidelines of the European Commission regarding heat pump type devices. According to the guidelines, the minimal SCOPnet value in Polish energy market conditions should be in excess of 3.5. In addition, it is seen that with the increase of outside temperature, the value of COPbin increases. Moreover, a comparison between GSHP and ASHP, analyzed in an earlier paper [2], is made. The more efficient heat generator is the GSHP pump. 


\section{Conclusions}

Taking into account the value of the energy efficiency coefficient, carbon dioxide emissions, and local climatic conditions, the ground heat pump meets the ecological heat generator conditions set by the European Commission. Thus, it can contribute to counteracting the intensification of the greenhouse effect phenomenon.

Author Contributions: A.G. created a calculation algorithm. S.S. performed the computations of SCOPnet. A.G. performed the computations of emissions. S.S. and A.G. analyzed the data and wrote the paper.

Acknowledgments: Meteorological data have been available thanks to the kindness of The Institute of Meteorology and Water Management-National Research Institute (IMGW-PIB). The paper was prepared by the Students' Scientific Society "Heat Engineer" at Bialystok University of Technology, and was financed by this university. Research was carried out at the Bialystok University of Technology at the Department of HVAC Engineering, and it was subsidized by the Ministry of Science and Higher Education Republic of Poland with funding for statutory R\&D activities. The paper was prepared using equipment which was purchased thanks to either the "INNO-EKO-TECH innovative research and didactic center for alternative energy sources, energy efficient construction, and environmental protection", a project implemented by the Technical University of Bialystok (PB) and co-funded by the European Union through the European Regional Development Fund under the "Programme Infrastructure and Environment", or "Research on the efficacy of active and passive methods of improving the energy efficiency of the infrastructure with the use of renewable energy sources", a project cofinanced by the European Regional Development Fund under the Regional Operational Programme of the Podlaskie Voivodship over the years 2007-2013.

Conflicts of Interest: The authors declare no conflict of interest. The founding sponsors had no role in the design of the study; in the collection, analyses, or interpretation of data; in the writing of the manuscript, and in the decision to publish the results.

\section{References}

1. Directive 2009/28/EC of the European Parliament and of The Council of 23 April 2009 on the promotion of the use of energy from renewable sources and amending and subsequently repealing Directives 2001/77/EC and 2003/30/EC. Off. J. Eur. Union 2009, 140, 16-62.

2. Sewastianik S.; Gajewski A. Mint: Seasonal coefficent of performance of a hybrid pump for a segment in a terraced house. Cieptownictwo Ogrzewnictwo Wentylacja 2017, 48, 151-154. (In Polish)

3. Gajewski, A.; Siergiejuk, J.; Szulborski, K. Carbon dioxide emission while heating in selected European countries. Energy Build. 2013, 65, 197-204.

4. Szelagowski, A. Sprężarkowe pompy ciepła. In Energetyka odnawilana w budownictwie. Magazynowanie Energii; Cwiejduk, D., Jaworski, M., Eds.; Wydawnictwo Naokowe PWN: Warsaw, Poland, 2018; pp. 229245.

5. Gajewski, A.; Sewastianik, S. Seasonal coefficient of performance SCOP of water-to-water vapour compression heat pump generating heat in a multifamily residential. Ciepłownictwo Ogrzewnictwo Wentylacja 2018, 49, 147-149. (In Polish)

6. Rubik, M. Pompy ciepła-część 8. Energetyczne, ekologiczne i ekonomiczne aspekty stosowaniasprężarkowych pomp ciepła. Cieplownictwo Ogrzewnictwo Wentylacja 2008, 12, 14-16. (In Polish)

7. Viessmann. Wytyczne projektowe Vitocal. Available online: http://www.viessmann.com/web/poland/pdf90.nsf/FEEC6BAA1863F270C1257ED500356683/\$FILE/WP\%20Vitocal\%20pompy\%20ciep\%C5\%82a\%20sol anka_woda,\%20woda_woda\%20od\%205,8\%20do\%20117,8\%20kW\%20(05.2015).pdf (accessed on 14 December 2018).

8. Baggs, S.A. Remote prediction of ground temperature in Australian soils and mapping its distribution. Solar Energy 1983, 30, 351-366.

9. Oleśkowicz-Popiel, C.; Wojtkowiak, J.; Prętka, I. Effect of surface cover on ground temperature season's fluctuations. Found. Civil Environ. Eng. 2002, 1, 151-164.

10. PN-EN 14825:2016-08. Air conditioners, chillers for liquid cooling and heat pumps with electrically driven compressors, for heating and cooling-Testing and evaluation under non-full load conditions and calculation of seasonal capacity. Available online: http://sklep.pkn.pl/pn-en-14825-2016-08e.html (accessed on 27 February 2019). 
11. PN-EN 12831-1:2017-08. Energy performance of buildings-Method of calculation of the design heat loadPart 1: Space heating load, Module M3-3. Available online: http://sklep.pkn.pl/pn-en-12831-1-201708e.html (accessed on 27 February 2019).

12. PGE Obrót, S.A. The shares of fuels and other primary energy sources used to the soled electrical energy production. Available online: https://pge-obrot.pl/O-Spolce/Struktura-paliw (accessed on 12 February 2019). (In Polish)

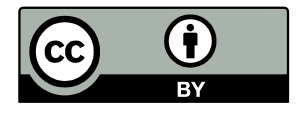

(C) 2019 by the authors. Licensee MDPI, Basel, Switzerland. This article is an open access article distributed under the terms and conditions of the Creative Commons Attribution (CC BY) license (http://creativecommons.org/licenses/by/4.0/). 